\title{
IDEA At Age Forty: Weathering Common Core Standards And Data Driven Decision Making
}

\author{
Vaughn Bicehouse, Slippery Rock University, USA \\ Jean Faieta, Edinboro University, USA
}

\begin{abstract}
Special education, a discipline that aims to provide specialized instruction to meet the unique needs of each child with a disability, has turned 40 years old in the United States. Ever since the passage of the Education for All Handicapped Children Act (P.L. 94-142) in 1975, every state has been directed to provide a free and appropriate education for all students with disabilities (Gallagher, 2000; Rothstein, 1995). The focus of this paper is to revisit the foundations of the special education movement in the United States to show how special education has progressed since 1975. The current Race to the Top movement impacts school districts across the nation, creating great concern about what this means for students with disabilities and how it affects their struggle to succeed within the public school domain. In fact, after 40 years, (P.L. 94-142) known as the Individuals with Disabilities Education Act, IDEA, is the current high stakes standards and assessment climate taking the "special" out of special education?
\end{abstract}

Keywords: IDEA; Inclusion; Race to the Top; No Child Left Behind; Special Education

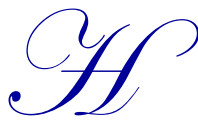

elen Keller once stated "I do not want the peace which passeth understanding, I want the understanding which bringeth peace" (Keller, 2003, p. 100). Her famous quote espouses the universal need for understanding that all people are part of a community. Throughout history, people have been connected to one another and to their local tribe, village, and community. Nevertheless, individuals with disabilities have too often been made to feel isolated and segregated. Society has not only been reluctant to accept people with disabilities, but it has also isolated them by forcing them into separate services within schools, employment, and living arrangements. In short, exclusionary practices were often the norm in society until the $18^{\text {th }}$ and $19^{\text {th }}$ centuries, when European philosophers and physicians began making occasional attempts to provide education to children with disabilities (Fakhoury \& Priebe, 2007). Consequently, the history of special education is a relatively short one - only about 200 years on the world stage and considerably less in the United States.

Today, as special education celebrates its $40^{\text {th }}$ birthday in the United States, much has changed regarding how America educates its students with disabilities. Congress passed the enactment of the Education for All Handicapped Children Act (P.L. 94-142) in 1975, and every state has been directed to provide a free and appropriate education for all students with disabilities in American public schools (Gallagher, 2000; Rothstein, 1995). The current cornerstone of special education, which can be traced back to the 1960 s, is to provide specialized instruction to meet the unique needs of each child with a disability.

During the 1960s, advocates for "handicapped students" pushed hard for federal funding, whereby students with disabilities could receive a free appropriate public education. In 1966, Congress took a step toward this aim when it set up the Bureau for Education of the Handicapped under Title VI of the Elementary and Secondary Schools Act (ESEA). Accordingly, the federal government funded a few programs that serviced only some students with disabilities (Martin, Martin, \& Terman, 1996). In 1970, Congress passed the Education of the Handicapped Act, P.L. 91-230, making available grants for states to set up programs that would educate students with disabilities. P.L. 91230 opened the door for servicing students with disabilities but stopped short of mandating services. During the same period (the late 1960s to early 1970s), several states passed laws that mandated local education agencies 
(LEAs) to provide limited special education services to students with disabilities and made available minimal financial support for such services.

Despite the passage of such laws and the funding provisions of P.L. 91-230, many children with disabilities still received limited or no educational services from their local public schools. In 1975, a Congressional report quantified that more than half of the "handicapped children" in the United States received no formal educational services (Education for All Handicapped Children Act (EAHCA), Sec. 3(b)(3)). Consequently, Congress enacted Public Law 94-142 to remedy this situation by requiring that all students with disabilities receive a free and appropriate education; it also established a funding mechanism to help defray the costs of special education programs (Rothstein, 1995).

As we commemorate forty years of IDEA, it is important to pause and ask how well the United States is doing educating and motivating students with disabilities. Given the current educational climate focused on high stakes testing, standards, student achievement, and school accountability, what is the current state of the field and how are the current issues and trends impacting students with disabilities? Children and adults with disabilities currently have more rights than ever before, but these rights are continually challenged in both the courts and the political arena. According to the National Council on Disability progress report (Young, 2011), problems with the noncompliance of the least restrictive environment provisions, free and appropriate education requirements, progress monitoring, confidentiality, and the availability of a continuum of placement options continue for many students with disabilities and their families. In fact, much work still needs to be done in the $21^{\text {st }}$ century, especially regarding the accessibility rights of children with disabilities in school. As the current Race to the Top legislation impacts school districts across the nation, there is great concern that students with disabilities are once again being left behind in their struggle to succeed within the public school domain (Mora, 2015).

\section{STATEMENT OF THE TOPIC}

In 2009, President Obama unveiled his Race to the Top Education Reform Program by declaring that "it is time to stop just talking about education reform and start doing it" (McGuinn, 2012, p.139). The Race to the Top initiative provides monetary incentives to states that can show progress in adopting standards and assessments that measure student growth using data systems. The goal of determining how to improve performance to make a difference for students - and, ultimately, for school systems and society - is not a new initiative. However, restructuring special education services to fit this most recent results-oriented plan is something distinct. In short, many in the field of special education are expressing concerns about how the impending changes are affecting children with disabilities. Change comes slowly and they do not always progress in the desired direction, particularly when looking at the history of people with disabilities in the United States.

What is the current state of special education in the United States? The adage that people who do not learn from history are doomed to repeat its mistakes seems apropos when we look at special education. The purpose of this paper is to research the foundations of the special education movement in the United States to determine how its journey has progressed. As the Race to the Top movement impacts school districts across the nation, we have a great concern for what this means for students with disabilities and what this does to their struggle to succeed within the public school domain. In fact, after IDEA's 40 years of progress, will we be undermined by the current high stakes standards and assessment climate that appears to be taking the "special" out of special education?

\section{REVIEW OF RELATED LITERATURE}

\section{Children's Rights}

Enduring a history of rejection in the public school system has been an ongoing way of life for many people with disabilities. The Constitutional struggle of children with disabilities has been a long and difficult voyage. The history of the legal status of children in America had progressed from a time when children were property, and education was for the elite. In Colonial America, children were totally under the control of their parents and deemed to be property under the law. Children usually worked to help support their family; if abandoned or orphaned, the children were put to work as indentured servants at unskilled jobs (Hinchey, 2001). 
Early laws reinforced the belief that children had no rights and that parents were given great latitude to discipline children as they saw fit. The Massachusetts Bay Colony passed the Stubborn Child Law in 1646, which espoused that parents could use a variety of disciplines to get their children to obey. This law even included capital punishment, although there is no written record of the death penalty ever being utilized (Hinchey, 2001). Such early laws were rooted in the doctrine of parens patriae (parent of the country). During colonial days, because children were considered property rather than people, the state supported parents by helping them discipline troublesome children. Ultimately, the abuse of children that at times resulted from this system motivated a gradual change in their status and over time led to the belief that children have some rights under the law.

In 1839, a court decision advanced the rights of children. The Crouse case in the Pennsylvania Supreme Court ruled against Mr. Crouse, a derelict father who wanted his daughter released from a juvenile home. As the father did not intend to take care of the child after she was released, the court for the first time protected the rights of a child over the desire of a parent's wishes. The state affirmed that it had the right to protect children inasmuch as they are the nation's future and a national resource. The decision advanced the idea that children must grow "into productive citizens" and that the government must ensure this by taking an interest in children's welfare (Hinchey, 2001). This finding expanded the parens patriae doctrine.

The right of the state to intervene in the life of a child differently from the way it intervenes in the life of an adult is based on the British legal system applying the parens patriae principle. The doctrine was interpreted as the inherent power of the king (state) to provide protection for persons who were not of full legal capacity. This jurisdiction was applied to cases of child neglect and abuse or on behalf of insane and incompetent persons. The essential element of this doctrine was its emphasis on the welfare of the child, allowing for an appropriate balance of social and economic interests. The court might well have limited its concern to dependent, neglected, and destitute children. However, in the Crouse case it extended its principles to include delinquent children who were dependent, neglected, and destitute (Hinchey, 2001).

In summary, the Crouse decision was a victory for all children in the United States. From that time on, children under parens patriae were protected/nurtured by the state under the law. However, the industrial age of the late $19^{\text {th }}$ and early $20^{\text {th }}$ centuries was both discouraging and hopeful times for children within the United States.

\section{Historical Background}

The late 1800s and early 1900s in America inspired colossal social change. Industrialization and immigration uprooted families and children in the United States. By 1900, four (4) out of 10 Americans were living in cities, and America was becoming an urban nation whose economic expansion was creating vast amounts of wealth. For this reason, America also faced new issues in World War I, the Roaring Twenties, and the Great Depression of the 1930s that led to sweeping social and political movements at home and abroad (Wall, 1970).

People called the final decades of the 1800s the Gilded Age, and this age gave birth to the Progressive movement. The changing society of this age confronted the issues of the Industrial Revolution, the rise of big business, the rise of American cities, the disparity between the rich and the poor, and a laissez-faire philosophy of the government that was ripe with corruption and scandal. The American family also changed dramatically because factory jobs kept parents out of their homes and away from their children. Many children were also employed as a cheap labor force and were often exploited and forced into inhumane conditions on the job. Because of this, the later part of the 1800s and early 1900s were considered a reform era in America and Europe. Children benefited greatly from this progressive movement because reformers began to promote education as the key to a better life (Wall, 1970).

Progressive reformers in the early 1900s focused on the need to educate America's youth and end dangerous child labor conditions. The progressive movement in education grew out of the philosophies of Rousseau, Pestalozzi, Froebel, and Francis W. Parker. Through the influence of John Dewey (1859-1952), they gathered force and espoused industrial training, agricultural and social education, and new instructional techniques (Wall, 1970). The progressives fostered the ideal that education is a holistic approach with the child at the center of concern. They advocated student-initiated activities which that de-emphasized pre-specified objectives and rote learning. In short, education was to contribute to each child's personal, social, and intellectual growth. They were, in fact, learning by 
doing, and the political reformers of the day were pushing mandatory education laws that would benefit all students, both cognitively and socially, regardless of their socioeconomic background (Winzer, 1986).

In the early 1920's Congress passed The Compulsory Education Act, which required all children ages 6 to 18 to attend school every year (Sperry, Daniel, Huefner, \& Gee, 1998). This progressive drive for education spilled over to the "handicapped population." Humanitarian sentiments in medicine and education began to champion the cause of disabled children and adults. Political reformers urged that teaching take place for "imperfect" or "incomplete" individuals to enable them to become productive citizens (Smith \& Luckasson, 1992). Special education was born out of an initial awareness that some students require a style or intensity of education different from typical education in order to achieve their potential. Although it gained momentum in the 1900s, this awareness evolved over many years and had its roots in Europe in the 1700s (Smith \& Luckasson, 1992).

\section{Early Reformers}

The individual most widely credited with being a pioneer of the special education movement is French physician Jean-Marc Itard (Hallahan, Kauffman \& Pullen, 2009). Itard was working with children with hearing difficulties when he discovered a young "mentally deficient" boy living by himself in the woods, naked and covered with scars, in 1799. Itard placed the boy, later named Victor, in a school for the deaf. Over the next five years, Itard implemented an extensive instructional regimen to meet Victor's individual needs. This regimen with detailed reports and techniques mirrors today's individualized educational programs (IEPs) and was used to develop special curricula for special needs children in the United States (Hallahan, Kauffman \& Pullen, 2009).

Although Itard is considered the father of special education, his work greatly influenced one of his students, Edouard Seguin, a utopian socialist who believed that with the help of science and technology, society could be open to everyone (Smith \& Luckasson, 1992). Seguin drew his ideas from the famous philosophers of the day, and he advocated that all people deserve happiness and freedom. He studied Itard's work on Victor to see how "idiots" could be taught and become productive members of society. In 1846, he published The Moral Treatment Hygiene and Education and Other Backward Children, which is considered one of the first special education books addressing the social and educational needs of children with handicaps (Hallahan \& Kauffman, 2000). Seguin subsequently opened a school for mentally retarded children in Paris and eventually moved to the United States where he received his M.D. from the City University of New York in 1861. Once in the United States, Seguin helped found the Association of Medical Officers of American Institutions for Idiots and Feebleminded Persons in 1876 (Hallahan \& Kauffman, 2000). This organization later became the American Association on Mental Deficiency (AAMD) and later yet the American Association on Mental Retardation (AAMR). As the oldest and largest interdisciplinary professional association in the field of mental retardation, AAMR remains a significant influence in shaping public policies.

Seguin believed that sensorimotor exercises could help stimulate learning for children with disabilities, and educators adopted his ideas into many schools in the United States in the 1800s. The legacy of his work can be found today in many aspects of special education such as the use of motor exercises as an aid to learning that was reintroduced in the 1960s in the United States is often part of an IEP in special education today (Hallahan \& Kauffman, 2000).

Seguin's work provided much of the foundation for the work of Thomas Gallaudet, Maria Montessori, and Samuel Gridley Howe, pioneers in the early delivery of educational services for children with disabilities. Gallaudet founded the first school for the deaf in Hartford, Connecticut, in 1817, and his work with the deaf population ultimately gave birth to Gallaudet University in Washington, D.C., which later founded in his honor. Meanwhile, Montessori-the first woman in Italy to receive a medical degree- became a promoter of early education for children and an educator of those with mental retardation. Montessori is best known for her advocacy efforts for the early education of children. She was reportedly so fascinated by Seguin's work that she copied all 600 pages of his book by hand (Hallahan \& Kauffman, 2000). Montessori built her ideas on Itard's work on sensory education and applied it to the early stages of child development. Finally, Howe, an American doctor, founded the Perkins School for the blind in 1829, where he served as a teacher and director of education. Howe was also a social reformer and educator who taught self-help skills to individuals with disabilities. 
The ideas of Itard, Seguin, Gallaudet, and Montessori, were groundbreaking and formational and continued to impact special education practices today. According to Hallahan and Kauffman (2000), some of their most important early concepts were:

- $\quad$ Providing individualized instruction;

- Sequencing educational tasks;

- Stimulating and awakening a child's senses;

- Carefully arranging a child's learning environment for maximum potential;

- Providing rewards for performance;

- Teaching functional skills; and

- Believing that every child has value.

These early pioneers believed in the human dignity of each child and found ways to educate students with varying challenges.

Despite such important accomplishments and idealism in the development of special education in America, the advancement of special education slowed greatly in the final part of the $19^{\text {th }}$ century. The late 1800 s were a bleak period for individuals with disabilities. The innovative, compassionate, and effective treatment that had been launched by the pioneers in special education was abandoned by the end of the $19^{\text {th }}$ century. Sadly, people with disabilities were institutionalized and segregated. Many factors contributed to this movement toward exclusion. Exclusive practices resulted from squabbles among professionals; an unwillingness to pay for the services; the social, political, and economic fallout of the Civil War; Darwin's theory of evolution; the industrialization and urbanization of America; and the backlash against the influx of immigrants to the United States (Hoffman \& Doris, 1979). The American public seemed willing to embrace the notion that special needs children were somehow inferior and were not open to improvement through education.

Succinctly put, the late 1800 s and early 1900 s were disheartening for individuals with disabilities. Classes and programs during this period relegated students with disabilities to an education through both warehousing and segregating them:

Confronting these deplorable conditions, the first special education classes in the United States were established during this time.

\section{Early Programs}

Special education classes in regular schools first appeared in the late $19^{\text {th }}$ century. In 1878 , two special education classes opened in Cleveland, Ohio, for children with behavior disorders (Hoffman \& Doris, 1979). Twenty years later, in 1898, Elizabeth Farrell pioneered a series of ungraded classes in New York City for special needs learners (Hoffman and Doris, 1979). Farrell's work teaching "backward" students was rooted in her beliefs that all children deserved to be educated. Farrell also started the Council for Exceptional Children (CEC) and was a leading advocate for special education services. Unfortunately, by the 1900s, most states opted for residential institutions over special education classes in regular schools. There were, however, a few exceptions in a few states such as: Rhode Island; Massachusetts; New York; New Jersey, and Pennsylvania.

While the idea of special education was developing in the early 1900 s, special education classes remained relatively uncommon, and only a small number of special needs students benefited from these classes (Smith \& Luckasson, 1992). Tragically, the other students were ignored, were institutionalized, died from a lack of care, or were hidden by their families, who feared discrimination and prejudice. Only a lucky few were educated by some of the first professionals in the field. The first formal training for teachers of special classes occurred in 1905 at the New Jersey Training School for Feebleminded Boys and Girls. The tuition for a six-week summer course in special education was $\$ 25$ (Smith \& Luckasson, 1992). This program was one of the few advances during what is known as a period of neglect in special education lasting from approximately 1860 to 1950. Sadly, in spite of these advances, the tone and prevailing attitudes toward people with disabilities were not very positive during this period. In fact, as late as 
1948, and only 12 percent of all children with a "handicap" were receiving any special education services in the United States (Hallahan \& Kauffman, 1988).

Even in those instances where special education services were available through the public schools (primarily in the large cities), decisions about placement, curriculum, and instructional methods were focused on promoting a separate, parallel structure for the special education schools, classes, and human resources (Burello \& Sage, 1979). Society viewed special education as separate and distinct instruction. One early report in 1923 reinforced this belief. This -report examined 44 cities (with more than 100,000 residents) that offered public school special education classes and found that 16 of these cities employed a combined total of 29 supervisors and six directors of special education. Special education administrators were viewed as experts, and the assumption was that technical expertise was a requirement for instructional practice. This concept reinforced a "mystique of specialness," which also encouraged strategies that segregated students (Burello \& Sage, 1979, p. 61). These early practitioners were put in charge of special teachers, created wrote special subjects and curriculum, and designed a special path to supervision in the field.

\section{Professional and Parent Organizations}

The acknowledgment that special education required a particular expertise was important in the development of the new profession. The National Education Association (NEA) approved the Department of Special Education in 1897. In 1922, the International Council for the Education of Exceptional Children (CEC) was founded (Aiello, 1976) when members of a summer class for teachers of special education decided to meet annually at Columbia University. Their goal was to share ideas and interface with special education services. Elizabeth Farrell, their professor, became the CEC's first president. As membership grew, the "international" was dropped from the title, and the organization became known as the Council for Exceptional Children. The CEC became affiliated with the NEA in 1924 and the World Federation of Education Associations in 1929. To date, the CEC remains the foremost special education professional society in the United States, attracting approximately 50,000 members and advocates for all individuals with disabilities (Baker \& Welkowitz, 2005).

A variety of other professional organizations has been important in the development of special education, including the American Occupational Therapy Association (AOTA), the National Association of Social Workers (NASW), and the American Physical Therapy Association (APTA). Parent groups and volunteer organizations also championed the cause of exceptional children. The Association for Retarded Citizens of the United States (ARCUS), founded in 1950 as the National Association of Parents and Friends of Mentally Retarded Children, worked to influence and require special education programs and services. Other influential groups included United Cerebral Palsy Associations Inc. (1949), the National Society for Autistic Children (1961), the Learning Disability Association of America (1963) established as the Association for Children with Learning Disabilities, and the Epilepsy Foundation of America (1968). These organizations created programs for those Americans with disabilities and advocated for special education services for students and their families (Smith \& Luckasson, 1992).

\section{Legislation and Litigation}

The various groups that fought for the disabled also fought to make their education a top priority. The first piece of legislation was not passed in the U.S. to benefit "handicapped individuals" until 1827. This Kentucky act set aside land for the Deaf and Dumb Asylum of Kentucky. In 1857, the first substantive law established a government-run hospital for "the insane". The facility, located in Washington, D.C., and later named St. Elizabeth's Hospital, was designed to deliver services to Army and Navy veterans. A year later, in 1858, Congress established what would later become Gallaudet University. It provided up to $\$ 3,000$ per year in tuition for services for the deaf, dumb, and blind (Ysseldyke, Algozzine, \& Thurlow, 1992).

In these early years of special education, government funds were scarce. The funding was given to support "experimental" programs to educate people with disabilities. In 1857, then-Governor of Massachusetts Henry Gardner vetoed a bill for funding the Massachusetts School for Idiotic and Feebleminded Youth, claiming that "educating fifteen idiotic-children borders on the ridiculous" (Ysseldyke et al., 1992, p. 27). Sadly there was a great reluctance to provide funding for special education services. One advocate of special education wrote that "the 
public funding of special education programs has been achieved and sustained only by the most arduous and persevering efforts" (Ysseldyke et al., 1992). In 1879, Congress appropriated \$250,000 for the purchase of supplies for the blind to enable them to be educated throughout the United States. However, this federal law was the last attempt at legislation/funding for special education by the government for the next 40 years (La Vor, 1979).

Hard economic times following the Civil War and public attitudes toward those with disabilities resulted in no legislation for the handicapped being enacted until the Soldier's Rehabilitation Act in 1918. Two years later, Congress passed the Citizens' Vocational Rehabilitation Act, which provided counseling, job training, job placement, and prosthetic devices to any deserving citizen (La Vor, 1979). The dire need for workers during World War II encouraged Congress to pass more legislation so those individuals with handicaps could fill necessary positions in American industry during the war. Although legislation was starting to offer some services for those with disabilities, the American attitudes of separation and segregation in education continued to prevail through the mid-1900s.

The 1950's and 60's witnessed the passage of many laws to benefit individuals with disabilities. Countless laws were enacted after years of lobbying from advocacy groups. One Supreme Court case revolutionized the opinion of "equal citizenship" under the law. Brown v. Board of Education (1954) stated that separate educational facilities are inherently unequal under the law. While this case focused on race, it opened the door for similar equal citizenship rights for persons with disabilities. Prior to this case, legislation primarily addressed the provision of institutional care or rehabilitative services to people with disabilities. For example, in the $19^{\text {th }}$ century, government legislation provided financial support for asylums, hospitals, and institutions for people with handicaps. In the first half of the twentieth eentury, laws were enacted to support the vocational rehabilitation of disabled war veterans and counseling and job placement for people with physical handicaps (Ysseldyke et al., 1992).

The late 1950s and early 1960s subsequently saw laws passed providing funds to establish state and community programs to service people with mental retardation. Federal legislation also followed that augmented funding to states for vocational education, assessment, teacher training, and special education services (Ysseldyke et al., 1992). Two political figures, John F. Kennedy and Hubert Humphrey, pushed for legislation and public acceptance of individuals with disabilities. Both had loved ones with mental retardation: President Kennedy, a sister and- Vice President Humphrey, a grandchild. Both men felt strongly about helping and, in 1961, President Kennedy established the President's Panel on Mental Retardation with a mandate to develop a national plan for mental retardation. Two years later legislation was passed that implemented many of the panel's recommendations (La Vor, 1979).

Federal laws were also passed providing funds for states to develop state and community programs and to construct facilities to service the population with mental retardation. Funding was also made available to establish community mental health centers and research, to develop demonstration centers for the education of those with disabilities, and to train personnel to work with those individuals. Despite these advances, as late as 1962, only 16 states included mentally retarded children under mandatory school attendance laws (Roos, 1970). In most states, all children with the mildest levels of disabilities were routinely excluded until the 1970s. Children without handicaps were required to attend school whereas children with handicaps were often told not to attend. The reasons for excluding children with handicaps varied by state and were often contradictory to today's values. One state Supreme Court excluded a young boy with cerebral palsy from school because he "produced a depressing and nauseating effect upon the teachers and school children" (Roos, 1970, p. 52).

The rights of children with special needs did steadily gain momentum. In 1958, following the Soviet launching of Sputnik I, Congress passed the National Defense Education Act to bolster the education of students in math and science. The law implied that gifted students should receive additional educational services so they can better compete in a changing society. In 1961, Congress passed legislation to support the training of teachers of the deaf and, in 1963, amended the law to provide for the training of teachers of students with hearing impairments, speech impairments, emotional impairments, and other health impairments (Ysseldyke et al., 1992). The tide of acceptance of children with disabilities grew with the increasing legislation and litigation. 
Starting in 1963, more federal and state legislation was passed to benefit students with disabilities. Congress appropriated grant funds to states to enable them to provide vocational education for students in need. In 1965, Congress passed the Elementary and Secondary Education Act (ESEA). Title I of ESEA established funds so that states could provide a "free and appropriate" public education to students with handicaps. Congress amended ESEA in 1967 to provide additional services for special needs students. The establishment of regional resource centers and deaf and blind service centers aimed to provide supports and testing for special education students. Funds were also authorized to make both personnel recruitment and information dissemination of special education services possible. In 1968, the Handicapped Children's Early Education Act funded model programs for preschool students with handicaps. Congress passed a great deal of legislation funding grants for special education throughout the 1960s. Although this funding was a positive step in the advancement of special education, the funding was primarily incentive in nature, with little in the way of specific guidelines and enforcement (Rothstein, 1995).

In the 1970s, the courts and Congress addressed the issue of how to mandate special education services and implement those services on a national level. At the start of the 1970s, special education was characterized by some familiar practices. First, the identification and placement of special needs students were haphazard, never the same, and often inappropriate. Second, African-American, Hispanic, and other ethnic children were disproportionately placed in special education programs. Third, parental involvement in the special education process was commonly discouraged. Fourth, special education placements were more often than not made with the goal of avoiding disruption in the regular classroom setting. Finally, special educators and regular educators often competed for funding and resources. The two groups seldom collaborated and did not work in a spirit of cooperation for the good of all students (Rothstein, 1995).

Two court cases in the early 1970s forever changed these practices and altered the landscape for children and their families with disabilities: Pennsylvania Association for Retarded Children (PARC) v. Pennsylvania and Mills v. Board of Education. In both cases, the district courts established that states could not deny education to children with disabilities without due process of the law. The Mills case set out a framework for what due process entailed so that the right to a free public education to all children with handicaps would occur. Both cases cited the constitutional safeguards of due process and equal protection under the $14^{\text {th }}$ Amendment. Although there is no constitutional right to education, the decisions reaffirmed that when states do provide education services, they must do so on equal terms for all students. In the Mills decision, the federal courts mandated that due process include the procedures related to labeling, placement, and decision making for a special needs child. The procedures should include a right to a hearing (with representation, a record, and an impartial hearing officer), a right to appeal, a right to have access to records, and a written notice of all phases of the process. These procedures subsequently became an integral component of the Education for All Handicapped Children Act and the Individuals with Disabilities Education Act (Rothstein, 1995).

The federal government felt pressure from the states and school districts after these two court decisions became law. Congress intervened in 1975 by passing the Education for All Handicapped Children Act (EHA; PL 94-142). The Civil Rights Movement created a favorable environment for the passage of this strong legislation, which provided federal grant funds to encourage states to comply with the decisions in the PARC and Mills The EHA mandated that the states prioritize funds for two groups: (1) handicapped children not receiving an education and (2) children who have the most severe handicaps who are receiving an inadequate education. Each state was to strive for full service for all students and submit plans to the federal government that showed they met the following requirements:

1. Due process safeguards: prior notices to parents of any change in their child's program, written in the parents' primary language, and including:

a. Access to relevant school records.

b. Opportunity for the independent evaluation of a child.

c. Impartial hearing with the right to legal counsel.

d. The right to remain in the placement desired by the parent until the proceedings are complete.

e. The appointment of a "surrogate parent" on behalf of children whose parents are unknown, unavailable, or wards of the state.

2. Least restrictive environment: handicapped children must be included in the mainstream and educated as much as possible with students who are not handicapped. 
3. Nondiscriminatory testing and evaluation: tests must be given in the child's primary language and be free of racially and culturally discriminatory language and bias.

4. Individualized educational programs: each child will receive this annual written plan that includes present levels of performance, short- and long-term goals, services to be provided, and the criteria to measure success.

5. Personnel development: plans to educate the regular and special education teachers as well as administrators on how to meet the law.

6. Participation of children in private schools: including free special education services when students are placed in those schools by state agencies or local districts. Students, however, should be educated in the least restrictive environment (LRE) when possible (Burello \& Sage, 1979).

When Congress passed this sweeping legislation in the mid-1970s, the belief was that more than eight million handicapped children lived in the United States at the time. Lawmakers recognized that the special education of those children was not met. Indeed, an estimated one million of these handicapped children were thought to be excluded entirely from the public school process and not going through the system with their peers. The lawmakers felt that it was in the national interest of the federal government to assist state and local governments to provide programs to meet the educational needs of all handicapped children (Burello \& Sage, 1979). In summary, Congress recognized the importance of special education for children with disabilities and passed the EHA.

In 1990, the EHA was amended, and the title changed to the Individuals with Disabilities Education Act (IDEA). The language of the act also changed with handicap replaced by disability throughout the law. IDEA included the following changes to EHA:

- added two additional categories: autism and traumatic brain injury

- provided individualized family service plans

- provided individualized transition plans

- $\quad$ provided individualized transition services by age 16

- required further public comments on defining attention deficit disorder

- affirmed that states can be sued in federal courts for violating the law (Gargiulo, 2009)

Even before passage of IDEA, Congress passed the Rehabilitation Act of 1973, whose Section 504 prohibited discrimination by federally funded programs against otherwise qualified persons with disabilities. The Rehabilitation Act protected the rights of students with handicaps to receive a free and appropriate public education. Although important in guaranteeing basic civil rights to individuals with special needs, it did not address many other areas of American society. Many of these guarantees were addressed on July 26, 1990 when President H.W. Bush signed the Americans with Disabilities Act (ADA).

The ADA outlawed discrimination against citizens with disabilities in employment, transportation, public accommodations, and telecommunications. The ADA mandates that employers not discriminate against qualified applicants with disabilities. It requires that all new buses, trains, and subways be accessible to persons with disabilities and easy for them to use. The ADA directs that new or refurbished public accommodations, such as hotels, stores, banks, and theaters, be accessible and that telephone companies provide relay services so that hearing impaired individuals can easily communicate (Smith \& Luckasson, 1992). Furthermore, the ADA expanded the protection found in the Rehabilitation Act to the private sector. Although education was not the primary focus of the ADA, it does apply to both public and private schools to ensure access to students with disabilities.

\section{Current Trends}

Special education in the United States in 2015-2016 is once again at a crossroads. Change occurred in 2004, when President George W. Bush signed the Individuals with Disabilities Education Improvement Act (IDEA 2004), which reauthorized and changed the earlier IDEA mandates. IDEA 2004 went into effect in July 2005, despite the opposition of many professionals, educators, service providers, and parents of special education children. When President Bush signed the bill, he said, 
“...in this bill, we're raising expectations for students. We're giving schools and parents the tools they need. We're applying the reforms of the No Child Left Behind Act, to the Individuals with Disabilities Education Improvement Act (IDEA) so schools are accountable for teaching every child. (The White House, 2005)"

The IDEA 2004 reforms included the following (Wright \& Wright, 2004):

- The elimination of benchmarks and short-term objectives on IEPs.

- IEPs can be amended in writing without reconvening an IEP meeting and no longer require the parent's written consent.

- Three-year IEPs are introduced as a pilot program.

- Parents must give school districts notice of specific due process complaints.

- Parents must pay out of pocket for due process hearings.

- School personnel will determine on a case-by-case basis whether to order a change in placement for a child with a disability who violates a code of student conduct.

- Manifestation determination review changed.

- Special education personnel must be highly qualified.

Many groups representing educators and other school-based professionals opposed the changes in IDEA 2004. Student and parent advocacy groups, the National Education Association, the National Association of School Psychologists, the American Speech-Language-Hearing Association, and at least 36 other organizations, including the ARC and Easter Seals all voiced opposition and concern about the change in special education mandates. Wendy Byrnes of DREDF warned that this Congress could have their place in history as the "permanent dismantlers of appropriate public education for millions of disabled children in the United States" (Robison, 2005). According to the Massachusetts Association of Special Education Parent Advisory Councils (MASSPAC), IDEA 2004 "turns back the clock at least 30 years in the advancement of disability rights" (Robison 2005, p. 3). IDEA 2004 "advocates the procedure of teaching all students with evidence-based instructional materials through general education" (Lerner \& Johns, 2015, p. 30).

IDEA 2004 has five new components. The first component required more inclusive placements for students placed in special education. This included placing students in general education classrooms for longer periods of time as appropriate to meet their individual needs. According to Lerner and Johns (2015), "general education classrooms can provide students with disabilities greater access to their general education peers, raise expectations for student performance, help general education students be more accepting of diverse students, and improve coordination between regular and special educators" (p. 29).

The second component is the response-to-intervention (RTI), a prevention model that limits or prevents academic failure by providing evidence-based teaching procedures for all students in the general education classroom. This tiered approach includes increasing intensity at each level for the students who do not show growth at a particular level. The students who do not respond make their way up the levels while leaving the other students who do respond at lower levels of instructional interventions. This approach is beneficial to students with disabilities because they remain in the general education classroom while being diagnosed with a disability.

The third component creates standards for teachers. In each state, teachers must meet highly qualified teaching standards in the special education field. Requiring consistent professional standards for teachers guarantees that all special educators are held to the same standard and treated fairly (Lerner \& Johns, 2015).

The fourth component focuses on assistive and instructional technology. The addition refers to "any item, piece of equipment, or product system, whether acquired commercially off the shelf, modified, or customized that is used to increase, maintain, or improve functional capabilities of individuals with disabilities" (Lerner \& Johns, 2015, p. 31). Assistive and instructional technology help create a wide array of activities in which students can participate, enabling them to feel like their general education peers. 
Finally, IDEA 2004 included a universal design for learning. This policy emphasizes "the idea that every curriculum should include alternatives to make learning accessible and appropriate for individuals with different backgrounds, learning styles, abilities, and disabilities in widely varied learning contexts" (Lerner \& Johns, 2015, p. 34). This policy allows students with disabilities to be included in the general education instruction and activities in the classroom as opposed to being placed in segregated settings and classrooms.

The changes to IDEA, combined with the current Race to the Top movement, leaves many unanswered questions about the future of special education services and its providers in the United States. Without question, the push for high academic achievement and the requirement that all students meet a level of proficiency that complies with the new standards leave many questioning the impact of the changes in the field of special education.

\section{CONCLUSION}

The desire to change educational services in the United States is nothing new. Throughout the history of the United States, both curricula, and instructional opportunities have continually changed as American society has changed. Students have been taught the necessary skills to live productively, act responsibly, and contribute to American society by becoming industrious citizens. America has been slow to include all children in this education arena. To paraphrase Lilly (1988), the move from segregated to inclusive education for all children is the culmination of nearly 180 years of development. Students with disabilities have often been left behind in the advancement of American educational practices.

As special education marks its $40^{\text {th }}$ birthday, much has changed regarding how America educates those with disabilities. Children and adults with disabilities have basic human rights guaranteed by years of litigation and legislation. Years of separation and segregation have ended, but the attitudes that brought about these practices remain in the hearts and minds of some Americans. If special education is going to continue to move forward in the $21^{\text {st }}$ century, the successful implementation must continue to rest upon the belief that inclusive schooling for all is a noble and moral obligation. Students must continue to receive the supports they need so that American education remains strong, democratic, and truly inclusive for all.

\section{AUTHOR BIOGRAPHIES}

Dr. Bicehouse spent 20 years in public education as: an inclusion teacher, general education teacher, emotional support teacher, learning support teacher, and special education supervisor. He has written many policy papers on special education and special education law and has created and implemented the Community Based Education curriculum for Butler Area School District. He has also recently presented his paper On Leaving Sam Behind at the International Conference on Disability in Hawaii. He has a B.A. from Grove City College, a B.S. from SRU, a M.A. from SRU, and a Doctoral degree from Duquesne University. For the past 9 years Dr. Bicehouse has been teaching higher education in Special Education at Pitt-Bradford, Edinboro University, and Slippery Rock University. He has partnerships with ARC, local ASD groups, and acts as a special education liaison for Prime Stage Theatre in Pittsburgh. His research interests include: data-driven decision making and its impact on students with disabilities, successful school and community inclusive models for individuals with disabilities, special education litigation and pedagogical best practices to create supportive environments for individuals with disabilities, using multiple intelligences to promote student achievement, best practices for students and adults with developmental disabilities, and best practices for students and adults with autistic spectrum disabilities.

Dr. Faieta has researched and practiced in the field of special education for the past 40 years. She started her career as a speech pathologist, graduating with a B.S. degree from California University of Pennsylvania. Upon the completion of her undergraduate degree, Dr. Faieta was awarded a graduate fellowship to complete her master's degree in mentally and/or physically handicapped K-12. She began her 10 year public school teaching career as a teacher of the learning disabled. She first started in the elementary level, proceeded to middle school and ended as a special education classroom teacher at the secondary level. It was at that point Dr. Faieta decided to explore additional teaching techniques in working with secondary students with learning disabilities. At that point in her career she applied and was accepted to become a researcher in the federally funded Learning Strategies Institute at the West Virginia University. The institute focused on the research based cognitive processing approach - The 
Strategies Intervention Model (SIM). The SIM technique was developed out of the University of Kansas, which was designated as one of the federally funded research institute for adolescents with learning disabilities. Dr. Faieta completed her doctoral degree from West Virginia University. At that point Dr. Faieta began her higher education teaching in the special education department at Edinboro University of PA. She currently is at the rank of full professor after 28 years at the university. She is a SIM trainer and a Content Enhancement professional developer for the University of Kansas. Her ongoing research interests has focused on documenting the effects of evidence research based practices in the field of education. Her research areas focus on students with learning disabilities, inclusion, teacher efficacy, quality teaching and instructional strategies, and working with families of children with disabilities.

\section{REFERENCES}

Aiello, B. (1976). Especially for special educators: A sense of our own history. Exceptional Children, 42, $244-252$.

Baker, L., \& Welkowitz, L. (2005). Asperger's syndrome. Mahwah, NJ: Lawrence Erlbaum Associates Publishers.

Burello, L., \& Sage, D. (1979). Leadership and change in special education. Englewood Cliffs, NJ: Prentice Hall Inc.

Fakhoury, W., \& Priebe, S. (2007). Deinstitutionalization and reinstitutionalization: major changes in the provision of mental healthcare. Psychiatry, 6(8), 313-316. doi:10.1016/j.mppsy.2007.05.008

Gallagher, J. (2000). Changing paradigms for gifted education in the United States In K. Heller (Ed.), International handbook of gifted education (pp. 681-694). Amsterdam, Holland: Elsevier.

Gargiulo, R.M. (2009). Special Education in Contemporary Society: Third Edition. Los Angles: Sage Publishers.

Hallahan, D., \& Kauffman, J. (1988). Exceptional children: Introduction to special education. Boston: Allyn \& Bacon Inc.

Hallahan, D., \& Kauffman, J. (2000). Exceptional learners. Boston, NJ: Allyn \& Bacon.

Hallahan, D. P., Kauffman, J. M., \& Pullen, P. C. (2009). Exceptional learners: Introduction to special education (11 th Ed.). Boston: Allyn \& Bacon.

Hinchey, P. (2001). Student rights: A reference handbook. Denver, CO: Library of Congress.

Hoffman, S. B., \& Doris, J. (1979). Educational handicap, public policy, and social history. New York: The Free Press.

Keller, H. (2003). The story of my life: The restored edition. New York: The Modern Library.

La Vor, M. (1979). Federal legislation for exceptional persons. Reston, VA: Council for Exceptional Children.

Lerner, J., \& Johns, B. (2015) Learning disabilities and related mild disabilities. Wadsworth Cengage Learning.

M. S. (1988). The regular education initiative a force for change in general and special education. Phi Delta Kappan, 71(7), 5-24.

Martin, E., Martin, R., \& Terman, D. (1996). The legislative and litigation history of special education. The Future of Children, 6, 25-3.

McGuinn, P. (2012). Stimulating reform: Race to the top, competitive grants, and the Obama education agenda. Educational Policy, $26(1), 136-159$.

Mora, J. M. (2015). Teachers' Perceptions of the Impact of Standardized Testing and Remediation on Students with Disabilities.

Random House. (2003). Helen Keller: The story of my life the restored edition. The Modern Library.

Roos, P. (1970). Trends and issues in education for the mentally retarded. Education and Training of the Mentally Retarded, 5 , 51-61.

Rothstein, L. F. (1995). Special education law (2 $2^{\text {nd }}$ ed.). White Plains, NY: Longman.

Sperry, David, Philip T.K. Daniel, Dixie Snow Huefner, E. Gordon Gee. (1998) Education Law and the Public Schools: A Compendium. Norwood, MA: Christopher-Gordon Publishers, Inc.

Smith, D., \& Luckasson, R. (1992). Introduction to special education. Boston: Allyn Bacon.

Wall, J. (1970). American adventures. New York: Scholastic Book Services.

White House. (2005). The Individuals with Disabilities Education Improvement Act (H.R. 1350) Retrieved from http://edworkforce.house.gov/issues/108th/education/idea/idea.htm

Winzer, M. A. (1986). Early developments in special education: Some aspects of enlightenment thought. Remedial and Special Education: RASE, 7(5), 42ஷ̀49

Wright, P. W. D., \& Wright, P. D. (2004) Idea 2004.Hartfield, VA: Harbor House Law

Ysseldyke, J., Algozzine, B., \& Thurlow, M. (1992). Critical issues in special education. Boston: Houghton Mifflin Company. 